Article

\title{
Production and Characterization of Hybrid Briquettes from Corncobs and Oil Palm Trunk Bark under a Low Pressure Densification Technique
}

\author{
Sunday Yusuf Kpalo ${ }^{1,2}$, Mohamad Faiz Zainuddin ${ }^{2, *}$, Latifah Abd Manaf ${ }^{2}$ and \\ Ahmad Muhaimin Roslan 3,4 \\ 1 Faculty of Environmental Sciences, Nasarawa State University, Keffi 961101, Nigeria; kpalosy@nsuk.edu.ng \\ 2 Faculty of Environmental Studies, Universiti Putra Malaysia, UPM Serdang, Selangor 43400, Malaysia; \\ latifahmanaf@upm.edu.my \\ 3 Faculty of Biotechnology and Biomolecular Science, Universiti Putra Malaysia, UPM Serdang, \\ Selangor 43400, Malaysia; ar_muhaimin@upm.edu.my \\ 4 Laboratory of Biopolymer and Derivatives, Institute of Tropical Forestry and Forest Products (INTROP), \\ Universiti Putra Malaysia, UPM Serdang, Selangor 43400, Malaysia \\ * Correspondence: z_faiz@upm.edu.my
}

Received: 29 January 2020; Accepted: 7 February 2020; Published: 21 March 2020

\begin{abstract}
The objective of this research was to investigate the quality of hybrid briquettes developed from corncobs (CC) and oil palm trunk bark (OPTB) under a low-pressure densification technique. The materials were combined in varying ratios of CC to OPTB (100:0, 75:25, 50:50, 25:75, 0:100) and wastepaper pulp ( $10 \%$ by weight) was added to each mixture as a binder. The briquettes were produced using a manually operated 20-tonne hydraulic piston press at $28{ }^{\circ} \mathrm{C}$ temperature and $\leq 7 \mathrm{MPa}$ compaction pressure. The mechanical strength of the briquettes was determined by the drop test and compression test methods, while a bomb calorimeter was used to determine the calorific values. The results showed that the physical properties of hybrid briquettes ranged from $9.24-10.00 \%$ moisture content, $0.38-0.40 \mathrm{~g} / \mathrm{cm}^{3}$ density, and $87.60 \%-92.00 \%$ water resistance. Mechanical strength showed a $98.28 \%-99.08 \%$ shatter index and $18.47-21.75 \mathrm{MPa}$ compressive strength, while calorific values ranged from $16.54-16.91 \mathrm{MJ} / \mathrm{kg}$. The hybrid briquettes fared better than the CC briquettes. The significance of this study lies in the production of briquettes with suitable physical, mechanical and thermal properties by utilizing OPTB which have hitherto not been used, mixed with corncobs. This could bring substantial environmental and socio-economic benefits to rural communities of the developing countries.
\end{abstract}

Keywords: Corncobs; oil palm trunk; bark; hybrid briquettes; density; compressive strength; calorific value; low pressure

\section{Introduction}

Biomass is organic and a renewable energy source. It is one of humanity's earliest sources of energy particularly in rural areas where it is often the only accessible and affordable source. [1]. Generation of energy from biomass materials offers the potential to reduce the greenhouse gas emissions from fossil fuels [2]. It can also guarantee energy security and tackle environmental problems [3], and contributes to its efficient management and to developing rural areas economically [4]. The potential of using biomass wastes in producing high energy concentrated fuels in the form of briquettes has been explored by researchers [5-7]. Corncobs and oil palm trunk (OPT) are examples of biomass wastes of plant origin, and are readily available in Nigeria. Their utilization, especially in rural communities, is basically as direct fuel, while their disposal is by open burning or being dumped 
and left to rot on farmlands. Generally, biomass display poor energy characteristics when used in their natural state [8,9]. They also show low bulk densities due to their porous structure which makes processing, shipping, storage and combustion difficult [10]. The disposal method is inefficient and leads to environmental pollution and degradation [11]. Biomass must be converted into a ready-to-use, high-energy resource in order to be considered as viable fuel [12]. Biomass densification offers a unique opportunity for converting biomass wastes with poor energy characteristics into solid fuels with high energy concentration. Additionally, densification increases bulk density, thereby optimizing transport and enabling the use of biofuel in areas far from where waste is generated. In turn, necessary homogeneity is achieved. In a rural setting where energy is never enough, briquetting remains the most applicable technology to produce energy in the form of solid fuel for cooking at the household level $[13,14]$.

Corncob is a process residue [15] produced after the harvesting of corn. Approximately 135 million tons of corncobs generated globally from 797 million tonnes (Mt) of corn production was reported in Muazu and Stegemann, [16]. Recent global production of corn puts the corn production estimate at 1031 million tonnes [17], with an expected increase in corncobs residue. Several studies have investigated the production and characterization of briquettes from corncob [18-21]. However, some have observed that corncob briquettes have a tendency to absorb water due to high particle porosity [16], and also displayed inadequate durability for handling and transporting after densification using low compaction pressure at room temperature [22,23]. Additionally, corncobs have a low bulk density of $104 \mathrm{~kg} / \mathrm{m}^{3}$ [24], low lignin content (5.6\%), low water-soluble carbohydrates $(1.1 \%)$ and low protein $(2.5 \%)$ that are largely responsible for forming solid bridge bonds during briquetting and thus, requiring a high compacting pressure and/or an external binder [23].

OPT is an annually available solid waste obtained in large quantities after the felling of oil palm trees [25]. Only about $40 \%$ of the OPT is utilized by oil palm-based plywood mills while the other $60 \%$ is discarded as waste due to its insufficient properties [26]. Additionally, the plywood manufacturing process includes debarking of the logs [27], which produces a lot of waste in the form of barks. In other climes, OPT is dumped on plantations, as it is considered valueless with no competition for other value-added products. However, it is lignocellulosic in nature (35.89\% lignin) and thus rich in energy content [28]. Lignin content of biomass can be used for heat and power production [29,30], and was confirmed to contribute to bulk density and durability of briquettes [31]. Ultimate and proximate analysis including the calorific value of OPT have shown that it has the potential to serve as a good feedstock for biofuel production [32,33]. There are however strong concerns about the amount of ash it may generate during combustion, as ash content in biomass above $4 \%$ may cause slagging [34]. Briquettes have been produced from some oil palm biomasses like the palm press fibers (PPF), palm kernel shell (PKS), mesocarp fiber (MF) and empty fruit bunch (EFB) [35-40]. Yet, very little or no attention has been given to OPT, as no studies can be traced to briquette made solely from OPT or mixed with another residue until now.

Briquetting can be done with a small amount of energy using low compaction pressure. Briquettes produced under a lower pressure technique have been reported to easily fall apart, while those under high pressure remained durable [41], However, a compaction pressure of $\leq 7 \mathrm{Mpa}$ has been used to produce low cost briquettes that are durable $[6,39,42]$. These researchers used binding agents, which is a requirement for low pressure densification. The purpose of the binder was to enable agglomeration of the material. Resource problems from the use of food products such as starch as binders [43] may arise, meaning non-edible and available products like waste paper, turned into pulp, can be used as alternatives. Papers are cellulosic in nature and have a binding ability due to the proteinaceous materials content, with an excellent adhesive property [44].

Previous studies have confirmed that a combination of different biomass materials enhances the quality characteristics of densified products $[23,45,46]$. The potential energy content and generation in large quantity presents corncobs and OPT as sustainable feedstock. This study anticipated that combining these materials will result in quality hybrid briquettes that will not only contribute to the 
energy mix but also to a more sustainable waste management strategy. Therefore, hybrid briquettes were produced from corncobs and the bark of oil palm trunk (OPTB) using a low-pressure technique and wastepaper pulp as a binder. The objective was to assess the quality of the briquettes in terms of physical, mechanical and thermal properties as a potential alternative energy source for domestic cooking applications.

\section{Material and Methods}

\subsection{Material Collection and Preparation}

Corncobs (Figure 1a) were collected from local farms in Nasarawa state, Nigeria, while the oil palm trunk was obtained from the local farmers in Serting Hilir, Malaysia. Waste papers were obtained from offices within the Universiti Putra Malaysia (UPM) premises. The bark of the oil palm trunk (Figure 1b) was separated from the trunk using an axe. Initial moisture contents of corncobs and OPTB as received were $23.34 \%$ and $75.01 \%$ wet basis (w.b.), respectively. All moisture contents presented in this paper are on a \% wet basis. Both materials were later chopped into small pieces and then sun dried to reduce the moisture content to $9.27 \%$ (w.b.) [47]. (Figure 2). A grinding machine (WARING COMMERCIAL) was used to grind the raw materials further and then sieved with a $2 \mathrm{~mm}$ sieve (ENDECOTTS Test Sieves) to obtain the desired particle size of $\leq 2 \mathrm{~mm}$. The waste papers were soaked in water for 2 days and then blended in a grinder to form pulp in accordance with the procedure described by Roy et al. [48]. A total of five different samples were prepared in varying ratios of corncobs (CC) to OPTB (Table 1) and each sample was mixed with wastepaper pulp as binder ( $10 \%$ by weight of sample mix).

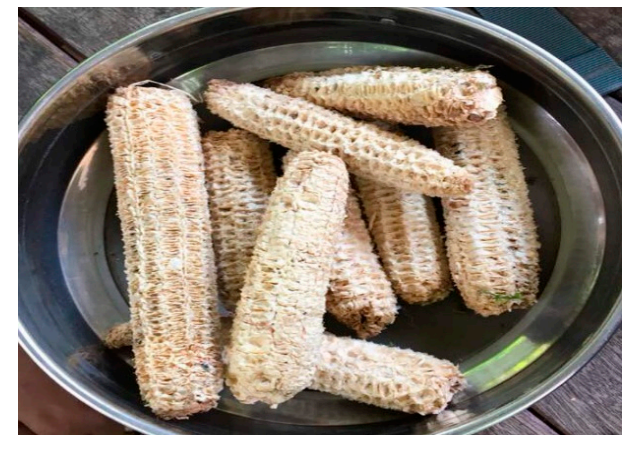

(a)

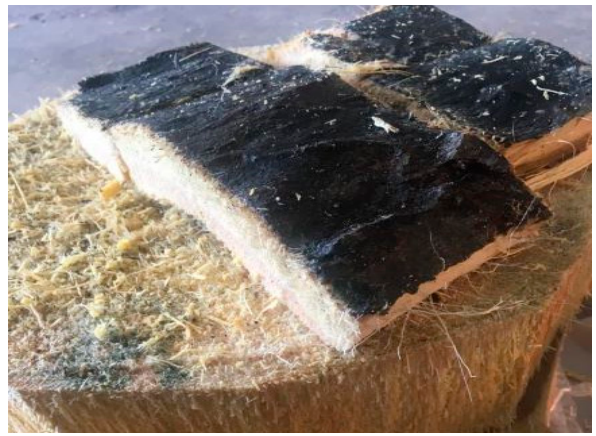

(b)

Figure 1. Samples of raw biomass waste used for the study (a) corncobs and (b) oil palm trunk bark (OPTB).

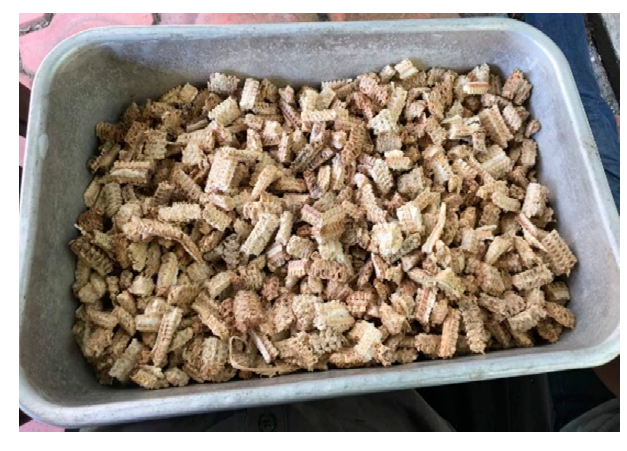

(a)

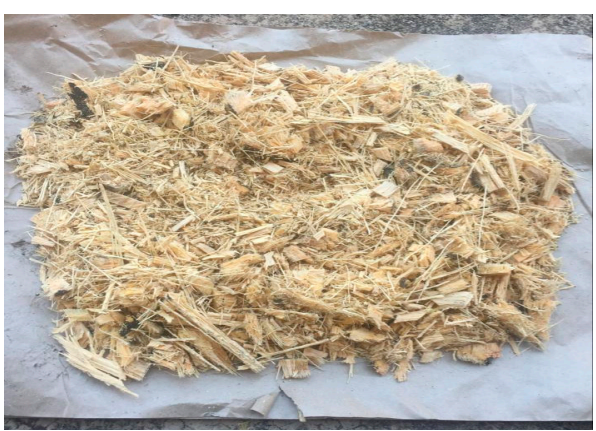

(b)

Figure 2. Samples of raw biomass waste in chopped form (a) corncobs and (b) OPTB.

\subsection{Material Characterization}

Proximate analysis was performed to estimate the percentage of volatiles, ash content and fixed carbon present in the raw materials. Volatile matter was determined by keeping the dried sample 
obtained after moisture content determination in a closed crucible at $925 \pm 20^{\circ} \mathrm{C}$ for seven minutes in a muffle furnace (Vulcan A-130) as per ASTM D-3175-18 [49]. The residual samples obtained after volatile matter determination were heated gradually in a muffle furnace (Vulcan A-130) to $700 \pm 50{ }^{\circ} \mathrm{C}$ for half an hour as per ASTM D-3174-12 [50]. The fixed carbon content was the value obtained after subtracting the value of the moisture content, volatile matter and ash content from $100 \%$. The ultimate analysis to determine the carbon, hydrogen, oxygen, nitrogen and sulfur content of the samples was performed in accordance with ASTM D3176-15 [51] using an element analyzer (LECO CHN628+S, Saint Joseph, MO, USA) at the material and characterization laboratory UPM. All determined values in both analyses are reported in this paper as dry basis (d.b.).

Table 1. Material composition of corncobs (CC) and OPTB briquettes.

\begin{tabular}{cccc}
\hline S/No & Sample Name & Corncobs & OPTB \\
\hline 1 & CC & $100 *$ & 0 \\
2 & OPTB & 0 & $100^{*}$ \\
3 & MIX 1 & 75 & 25 \\
4 & MIX 2 & 50 & 50 \\
5 & MIX 3 & 25 & 75 \\
\hline
\end{tabular}

${ }^{*}$ Control.

\subsection{Briquette Production}

The briquettes were formed in a cylindrical mold with an inner diameter of $56.6 \mathrm{~mm}$, a height of $74 \mathrm{~mm}$ and a rod with a $14.4 \mathrm{~mm}$ outer diameter placed in the center to create a hole in the middle of the briquette. The hole helps to increase porosity and oxygen supply, thereby improving briquette combustion. The mold was filled with the mixtures and densified under constant operating conditions (temperature of $28^{\circ} \mathrm{C}$, pressure of $\leq 7 \mathrm{MPa}$ ) with a manually operated 20-tonne air hydraulic piston press (KENNEDY Model HBP020, UK). Ten briquettes were produced from each sample and their initial densities were measured immediately after ejection from the mold. The resultant briquettes (Figure 3) were placed on a flat surface and left to air dry in a closed room with adequate air ventilation for 30 days before testing the properties.

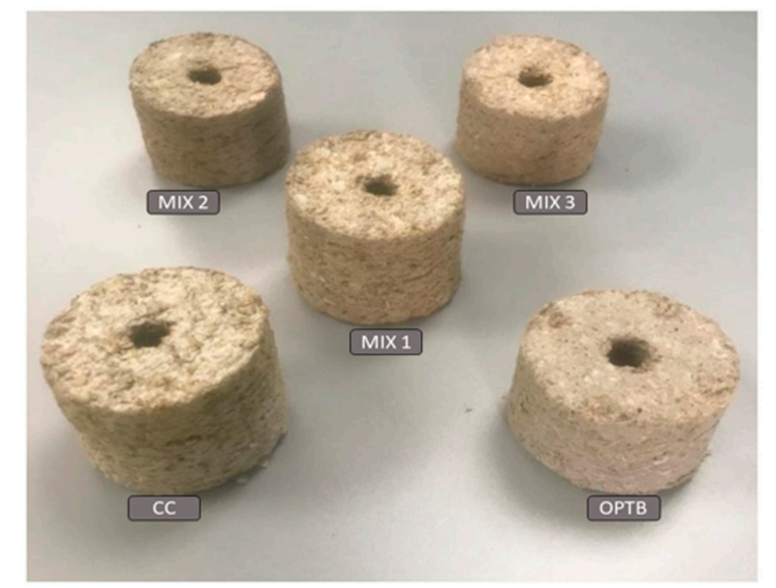

Figure 3. Briquettes samples made from corncobs, OPTB and their mixtures using a manual press.

\subsection{Briquette Characterization}

\subsubsection{Moisture Content}

Moisture content was determined by oven-dried methods in accordance with ASTM D2444-16 [52]. Each briquette was weighed and then oven-dried at $105 \pm 3{ }^{\circ} \mathrm{C}$ to constant masses in $24 \mathrm{~h}$. The loss in 
mass, expressed as a percentage of final oven-dried mass was taken as the moisture content of the briquettes. The moisture content was calculated by equation

$$
M C=\frac{W_{1}-W_{2}}{W_{2}} \times 100
$$

where $M C=$ moisture content, $W_{1}=$ wet weight, $W_{2}=$ weight after drying.

\subsubsection{Density}

The density of briquettes was determined according to ASTM D2395-17 [53]. The density of briquette was calculated by dividing the mass of the briquette by its volume. The volume was determined by measuring the diameter, height and central whole diameter at different points using a Vernier caliper, while the mass was measured with a digital weighing balance (Model AND GF 3000). The density of briquettes was determined 30 days after the briquetting process. The density was calculated by:

$$
\rho=\frac{m}{V}
$$

where $\rho=$ Density, $m=$ mass of biomass briquette, $V=$ volume of biomass briquette.

\subsubsection{Water Resistance}

The water resistance test was carried out in accordance with the procedure described in Davies and Davies, [54]. A digital weighing balance (Model AND GF 3000) was used to measure the initial weight of each sample briquette and then dunked in water for $2 \mathrm{~min}$. A stopwatch was used to time the process. The briquette's weights were measured again and the relative change in weight was recorded. Percentage water absorbed was calculated using the following equation

$$
\% \text { water absorbed by briquette }=\frac{W_{2}-W_{1}}{W_{1}} \times 100
$$

where $W_{2}$ = final weight of briquette after immersion and $W_{1}=$ initial weight of briquette before immersion.

Water resistance index is now calculated using equation

$$
\text { Water resistance }(\%)=100 \%-\% \text { water absorbed by briquette. }
$$

\subsubsection{Shatter Index}

This property was determined according to ASTM D440-86 [55]. The procedure involved weighing and recording the initial mass of the briquette, followed by subjecting the sample to a gravitation fall from a constant 2-m height. The drop is repeated three times and each time the sample was passed through a sieve $(2.36 \mathrm{~mm})$, while the mass of the briquette retained on the sieve was recorded [56]. The shatter index of each briquette was calculated by the equation:

$$
K=\frac{B_{z}}{B} \times 100
$$

where $K=$ shatter index, $B_{z}=$ weight of briquette after shattering, $B=$ weight of briquette before shattering.

\subsubsection{Compressive Strength}

The compressive strength of a briquette is measured by the maximum load it can withstand before cracking or breaking. This load estimates the weight a briquette can withstand during storage. Compressive strength of briquettes was determined using a universal testing machine (INSTRON 3382) with a load cell capacity of $50 \mathrm{kN}$ and a cross-head speed was $1 \mathrm{~mm} / \mathrm{min}$ in accordance with ASTM 
D2166-85 [57]. The briquette was placed in between the plates of the machine and was subjected to uniform loading until failure or rupture.

\subsubsection{Calorific Value}

The calorific value of the briquette was determined using the IKA C2000 Basic bomb calorimeter in accordance with ASTM D5865-13 [58]. One gram of sample was pelletized, placed in a sample holder (crucible) and then transferred to a steel capsule from the bomb calorimeter. The test was performed at the Institute of Tropical Agriculture and Food Security (ITAFoS), UPM.

\subsection{Data Analysis}

Samples of briquettes were selected by a simple random sampling method in each of the five categories and their properties (density, moisture content, water resistance, compression strength, shatter index and calorific value) were tested and replicated four times. The test data obtained were subjected to Analysis of Variance (ANOVA) and Fisher's Least Significance Difference (LSD) test to determine the significant differences between the various treatments of the briquettes. All significance tests in this study were conducted with $p<0.05$.

\section{Results and Discussion}

\subsection{Proximate and Ultimate Analysis of Raw Materials}

The values in Table 2 shows the proximate and ultimate analysis of corncobs and OPTB in this study, along with comparative values found in the literature. Corncobs had a lower ash content compared with the OPTB. Studies have found a higher amount of ash in barks of several forest species attributed to the higher mineral content in the bark than in the wood $[59,60]$. The higher percentage of ash content of the OPTB suggests the possibility of more ash removal for OPTB than corncobs when similar quantities of their briquettes are burnt. According to Duca et al. [4], high ash content feedstock may also result in a high level of operating discomfort among home owners when used for residential heating. Mendoza-Martinez et al. [12], added that it is desirable for the feedstock materials and consequently for the final products to have a low ash content, high energy as well as fixed carbon. The volatile matter and fixed carbon values obtained for this study are within the range reported by the literature listed in Table 2. The results from the ultimate analysis shows that both materials met the requirement of the DIN 51731 standard [61] guiding values except for sulfur, which was found to be slightly above $<0.08 \%$. This implies that the thermal properties are good enough for heat production.

Table 2. Proximate and ultimate analysis of corncob and OPTB raw materials.

\begin{tabular}{ccccccc}
\hline Properties & \multicolumn{2}{c}{ This Study } & \multicolumn{3}{c}{ Literature Data } \\
& Corncobs & OPTB & \multicolumn{2}{c}{ Corncobs } & \multicolumn{2}{c}{ OPT } \\
\cline { 4 - 7 } & & & {$[1]$} & {$[62]$} & {$[32]$} & {$[33]$} \\
\hline Moisture content (\% w.b.) & 9.27 & 9.27 & NA & 8.28 & 7.16 & NA \\
Volatile matter (\% d.b.) & 74.39 & 78.92 & 87.40 & 71.16 & 82.60 & 86.70 \\
Ash content (\% d.b.) & 2.42 & 8.01 & 1.10 & 2.70 & 5.27 & 3.35 \\
Fixed carbon (\% d.b.) & 13.92 & 3.80 & 11.50 & 17.78 & 4.97 & NA \\
Carbon (\% d.b.) & 42.70 & 42.12 & 49.00 & 49.00 & 42.72 & 51.41 \\
Hydrogen (\% d.b.) & 6.49 & 6.48 & 5.40 & 5.40 & 5.61 & 11.82 \\
Oxygen (\% d.b.) & 50.41 & 50.83 & 44.50 & 44.20 & 51.25 & 51.16 \\
Nitrogen (\% d.b.) & 0.25 & 0.32 & 0.50 & 0.40 & 0.44 & 0.17 \\
Sulfur (\% d.b.) & 0.15 & 0.25 & 0.20 & NA & NA & NA \\
Calorific value (MJ/kg d.b) & 16.13 & 16.71 & NA & 17.36 & NA & 17.47 \\
\hline
\end{tabular}

NA means not available. 


\subsection{Briquette Characterization}

\subsubsection{Moisture Content}

Moisture content is an important parameter for evaluating changes that may occur in the physical conditions of briquettes during storage and transport. The moisture content values obtained in this study ranged from $9.24 \%$ for OPTB and a hybrid type (MIX 3) to $10.24 \%$ for CC briquette (Table 3, Figure 4). The briquettes made with a higher percentage of OPTB material exhibited a lower moisture content compared to those with a higher percentage of corncobs material. However, ANOVA showed that there is no significant difference in the moisture content values of the briquettes $(p<0.05)$. (Table 4$)$. The values obtained are similar to those of rice husk briquettes with cassava starch, but lower than the rice husk briquettes with cassava peel binder found in Arewa et al. [63]. According to Chin and Siddiqui, [64], the tolerance level of moisture content for briquette is between $8 \%$ and $12 \%$, which may depend on the nature of the feedstock.

Table 3. Least Significance Difference test for the properties of briquettes.

\begin{tabular}{ccccccc}
\hline & $\begin{array}{c}\text { Moisture Content } \\
\text { (\% w.b.) }\end{array}$ & $\begin{array}{c}\text { Density } \\
\left(\mathbf{g} / \mathbf{c m}^{\mathbf{3}}\right)\end{array}$ & $\begin{array}{c}\text { Water } \\
\text { Resistance (\%) }\end{array}$ & $\begin{array}{c}\text { Shatter } \\
\text { Index (\%) }\end{array}$ & $\begin{array}{c}\text { Compressive } \\
\text { Strength } \\
\mathbf{( M p a )}\end{array}$ & $\begin{array}{c}\text { Calorific } \\
\text { Value } \\
\mathbf{( M J} / \mathbf{k g ~ d} \text { d.b.) }\end{array}$ \\
\hline CC & $10.24^{\mathrm{a}}$ & $0.35^{\mathrm{a}}$ & $86.20^{\mathrm{b}}$ & $99.20^{\mathrm{a}}$ & $10.26^{\mathrm{a}}$ & $16.65^{\mathrm{a}}$ \\
OPTB & $9.25^{\mathrm{a}}$ & $0.43^{\mathrm{c}}$ & $93.20^{\mathrm{a}}$ & $99.05^{\mathrm{a}}$ & $22.33^{\mathrm{c}}$ & $17.78^{\mathrm{a}}$ \\
MIX 1 & $10.00^{\mathrm{a}}$ & $0.38^{\mathrm{b}}$ & $87.60^{\mathrm{b}}$ & $98.28^{\mathrm{a}}$ & $18.47^{\mathrm{b}}$ & $16.54^{\mathrm{a}}$ \\
MIX 2 & $9.75^{\mathrm{a}}$ & $0.39^{\mathrm{b}}$ & $88.30^{\mathrm{b}}$ & $98.16^{\mathrm{a}}$ & $21.09^{\mathrm{c}}$ & $16.65^{\mathrm{a}}$ \\
MIX 3 & $9.24^{\mathrm{a}}$ & $0.40^{\mathrm{b}}$ & $92.00^{\mathrm{a}}$ & $99.08^{\mathrm{a}}$ & $21.75^{\mathrm{c}}$ & $16.91^{\mathrm{a}}$ \\
\hline
\end{tabular}

Means with the same letter(s) in a column for briquette properties are not significantly different $(p<0.05)$.

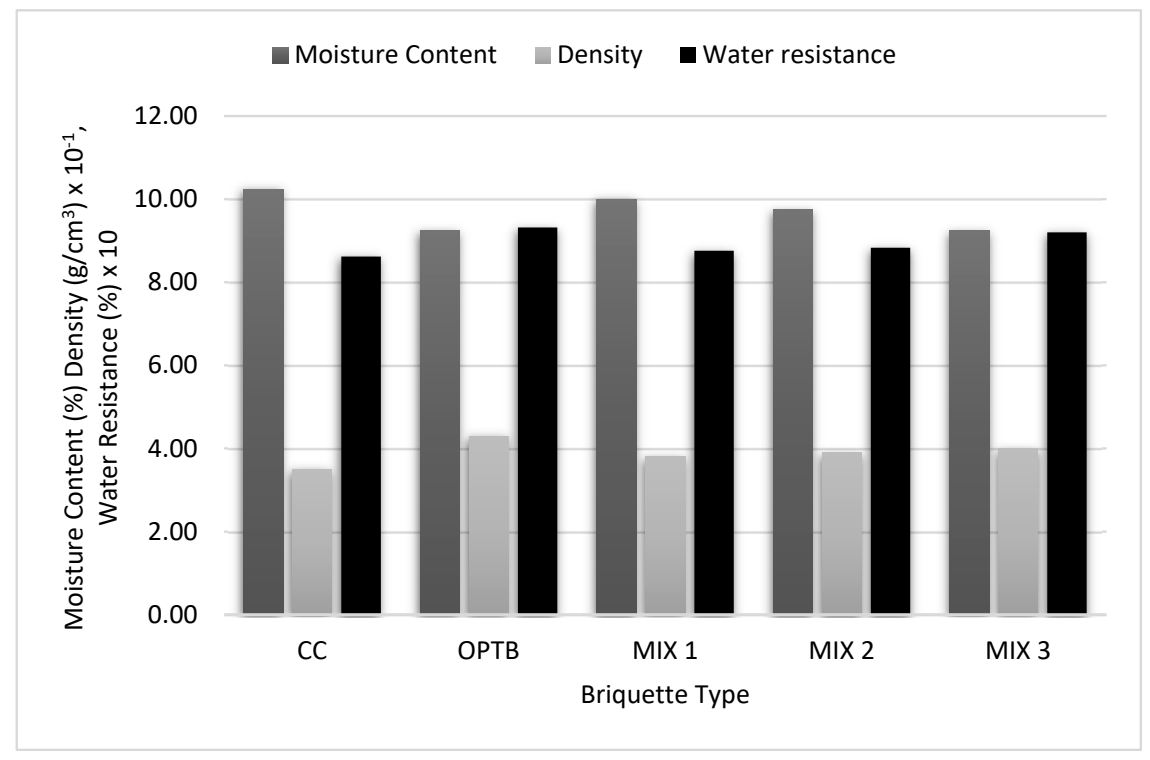

Figure 4. Moisture content, density and resistance to water penetration of briquettes.

Studies have reported that a moisture content that is less than $4 \%$ or $5 \%$ will reduce the stability of briquettes $[65,66]$ and make the briquette too dry, hence making it burn out quickly [67]. Generally, a high moisture content above the tolerance level can be detrimental to the briquette or the equipment that uses it. Nonetheless, it could positively influence compression strength and shatter index [56]. High moisture content can make briquettes susceptible to poor combustion properties such as low heat output, low combustion temperature, and long fuel residence time in the combustion chamber [68]. This could lead to excessive emission of fumes and risk of explosion if burnt in a furnace [69]. Briquettes 
with high humidity can cause a boiler to shut down [67], have lower durability, easily become eroded and broken [70], and can be ruined due to microbial decomposition, resulting in a substantial loss of dry matter during storage and transport [66]. The hybrid and control briquettes in this study are good enough to burn and conform to the tolerant level. However, MIX 1 briquette is more likely to attract moisture.

Table 4. ANOVA for properties of briquettes.

\begin{tabular}{|c|c|c|c|c|c|}
\hline & Source of Variation & SS & Df & MS & $p$-Value \\
\hline \multirow[t]{3}{*}{ Moisture content } & Test samples & 3.20 & 4 & 0.80 & $0.54^{\mathrm{a}}$ \\
\hline & Error/Residuals & 15.00 & 15 & 1.00 & \\
\hline & Total & 18.20 & 19 & & \\
\hline \multirow[t]{3}{*}{ Density } & Test samples & 0.01 & 4 & 0.003 & $0.000003^{b}$ \\
\hline & Error/Residuals & 0.002 & 15 & 0.0001 & \\
\hline & Total & 0.01 & 19 & & \\
\hline \multirow[t]{3}{*}{ Water resistance } & Test samples & 100.56 & 4 & 25.14 & $0.02^{b}$ \\
\hline & Error/Residuals & 89.31 & 15 & 5.95 & \\
\hline & Total & 189.87 & 19 & & \\
\hline \multirow[t]{3}{*}{ Shatter index } & Test samples & 3.88 & 4 & 0.97 & $0.52^{\mathrm{a}}$ \\
\hline & Error/Residuals & 17.35 & 15 & 1.16 & \\
\hline & Total & 21.234 & 19 & & \\
\hline \multirow[t]{3}{*}{ Compressive strength } & Test samples & 397.92 & 4 & 99.48 & $0.0000002^{b}$ \\
\hline & Error/Residuals & 41.79 & 15 & 2.79 & \\
\hline & Total & 439.70 & 19 & & \\
\hline \multirow[t]{3}{*}{ Calorific value } & Test samples & 4.10 & 4 & 1.03 & $0.21^{a}$ \\
\hline & Error/Residuals & 9.36 & 15 & 0.62 & \\
\hline & Total & 13.46 & 19 & & \\
\hline
\end{tabular}

${ }^{\text {a }}$ Not significant: ${ }^{\mathrm{b}}$ Significant: $(p<0.05)$.

\subsubsection{Density}

Density is an important parameter for the briquetting process. The density of the feedstock, binder, briquetting pressure, temperature and time, to a large extent, determine the eventual density of the briquette [71]. The higher the density in briquettes, the higher the energy/volume ratio. The burning time may be longer [72], however, other combustion properties of such briquettes may be negatively affected [73]. The CC briquette displayed the lowest density of $0.35 \mathrm{~g} / \mathrm{cm}^{3}$ while the OPTB briquette had the highest density at $0.43 \mathrm{~g} / \mathrm{cm}^{3}$ (Table 3, Figure 4). ANOVA shows that densities of the briquettes are significantly different $(p<0.05)$ (Table 4$)$. However, LSD shows that densities for the hybrid briquettes (MIX 1, MIX 2 and MIX 3) are not significantly different (Table 3). Density values observed in this study are similar to briquettes produced with a carbonized coffee husk $\left(0.30-0.39 \mathrm{~g} / \mathrm{cm}^{3}\right)$ using different manual presses [74] and rice husk and bran briquettes $\left(0.44 \mathrm{~g} / \mathrm{cm}^{3}\right)$ made with cassava starch wastewater [42].

The observed difference between the CC and OPTB briquettes can be ascribed to the higher lignin content and fineness of the OPTB materials. According to Antwi-Boasiako and Acheampong, [56], briquette density is affected significantly by the raw material particle size, wherein finely ground materials make very dense briquettes. This was confirmed by Mitchual et al. [41] suggesting that raw material with finer particles provides a larger surface area for bonding, which results in the production of briquette with a higher density. Owing to the inclination to absorb water, the lower values of $\mathrm{CC}$ briquette could be due to a decrease in the briquette weight or a rise in the briquette volume after drying and stabilizing, as observed by Okot et al. [21]. Studies have also noted that briquettes produced from hydraulic piston presses have unit densities lower than $1.00 \mathrm{~g} / \mathrm{cm}^{3}$ because of limited pressure $[56,66]$. For economic purposes, low density raises the costs of briquette transportation and decreases the energy density [12]. Blending corncobs and OPTB improved the density of the briquettes 
and the higher the proportion of OPTB material, the higher their densities. The hybrid briquettes produced in this study are suitable for transportation, storage and handling.

\subsubsection{Water Resistance}

Studies on the water resistance test has been performed to determine the rate at which briquettes can withstand degeneration in high humidity or water exposure [75]. The OPTB briquette recorded the highest resistance to water penetration with a value of $93.2 \%$ followed by the MIX 3 briquette with a value of $92.0 \%$. (Table 3, Figure 4). ANOVA shows that water resistance indices of the briquettes are significantly different $(p<0.05)$. (Table 4$)$. The values obtained in this work compares favorably with values ( $>70 \%$ resistance) obtained in Rajaseenivasan et al. [76] for sawdust and neem powder briquettes. The CC briquette recorded the least resistance $(86.2 \%)$, most likely from due to the low density and porosity of corncob particles. Earlier, Pinto et al. [77] had observed that particle porosity from existence of a capillary network in corn cob gives rise to its tendency to absorb water. Contrastingly, the hybrid briquettes showed a gradual rise in resistance to water penetration. This is an indication that with increased quantity of OPTB material, the hygroscopic property of the hybrid briquettes showed a decrease in water absorption capacity. OPTB has a fibrous structure $[28,78]$ and the positive effects of that structure on the improvement of briquette's water resistance was noted in Yaman et al. [79].

In a test carried out by Centre de Rescherches Agronomiques de 1'Etat Gembloux (CRA) and reported in Eriksson and Prior, [73], briquettes were subjected to humid air for a period of 21 days in an atmosphere of $20^{\circ} \mathrm{C}$ and $95 \%$ humidity. The recorded results showed that an elongation of less than $30 \%$ ( $>70 \%$ resistance) was considered acceptable and less than $20 \%$ ( $>80 \%$ resistance) was suggested to be most ideal. Richards [80] further added that a water resistance index of $95 \%$ would be a reasonable target for most briquette types which maintain integrity after $30 \mathrm{~min}$ of immersion. In this study, all the categories of briquettes fall within the acceptable quality value $(>70 \%)$ based on the CRA criteria. Briquettes may absorb moisture from the air during handling, transportation and storage. If this is prolonged, they will swell to decrease the density and lead to total disintegration. Water resistance also influences the combustion of briquettes as it affects their heat values. The lifetime of briquettes is limited under humid conditions and thus the reason why they should be stored under dry cover. It is important that briquettes display a high resistance to water penetration to avoid decay and growth of fungi during storage particularly if the feedstock are agricultural residues. This research finding suggests that the hybrid briquettes are good enough for transportation and storage, and that a mild exposure to moisture would not have any serious damaging effect on them.

\subsubsection{Shatter Index}

Shatter indices are a direct means of gauging the strength of briquettes for the purposes of handling, transportation and storage. Results in Table 3 and Figure 5 shows that the CC briquette recorded the greatest shatter index of $99.20 \%$ which was closely followed by the MIX 3 briquette with a value of $99.08 \%$. However, ANOVA (Table 4 ) shows that shatter indices of the briquettes are not significantly different $(p<0.05)$. These results can be likened to the best shatter indices $(98.21 \%$ and $98.17 \%)$ obtained for sawdust and charcoal briquettes in Ajiboye et al. [81]. According to Borowski et al. [82], the shatter index of briquettes should be at least $90 \%$. In a previous study, a minimum value of $50 \%$ was considered an acceptable shatter index for fuel briquettes developed for industrial and domestic applications [80]. The addition of paper pulp as a binder is responsible for the agglomeration of the materials, which resulted in a strong bonding of particles. This was confirmed by the presence of paper mill waste, which increased the shatter index of the briquettes obtained in Yaman et al. [79]. Similarly, higher ratio of paper pulp resulted in a higher percentage of shatter resistance of briquettes in Kpalo et al. [11]. The shatter index of a briquette shows its ability to produce fewer fines during handling. The higher the value of the shatter index, better the quality of briquette [83] and indicative of high durability to gravitational deterioration [56]. The shatter indices of the hybrid briquettes in this study reveals that they can be good for transportation and storage. 


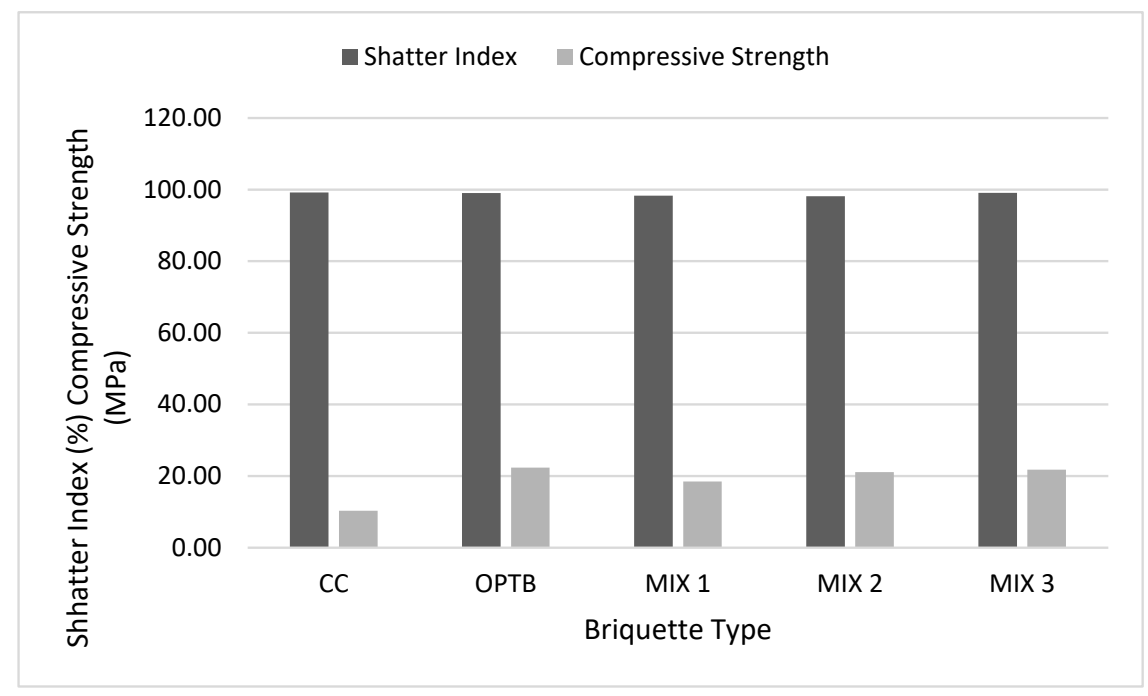

Figure 5. Shatter index and Compressive strength of briquettes.

\subsubsection{Compressive Strength}

Compressive strength is the maximum crushing load a briquette can withstand before cracking or breaking. Apart from shatter index, it is another index used to assess briquette's ability to be handled, packed and transported. The strength of briquettes depends on factors such as particle size, moisture content, compaction parameters and material type [84]. Table 3 and Figure 5 shows that the values for compressive strength of briquettes ranged from 10.26 to $22.33 \mathrm{MPa}$ and are significantly different $(p<0.05)$ as assessed by ANOVA (Table 4$)$. The hybrid briquettes displayed better compressive strengths than those of briquettes made from agro-based materials [85], pine needles [86] and banana tree waste [67]. The CC briquette displayed the greatest variation, while the OPTB, MIX 2 and MIX 3 briquettes exhibited higher compressive strengths in similar manner with their reported density values. The results are also consistent with the observation by Jamradloedluk and Wiriyaumpaiwong, [87] that briquettes produced from materials with higher density can withstand higher ultimate stress in comparison to those of lower density materials. Wu et al. [88] observed that the extremely high compressive strength suggests the presence of the strong bonding forces between the particles within HT biomass briquette. Aside the density of the raw materials, the paper pulp used as binder in this work also contributed to the compressive strength of the briquettes. Increase in quantity of paper mill waste correspondingly increased the compressive strengths of briquettes in Yaman et al. [79]. Generally paper waste does not crumble when compacted properly due to having an excellent binding ability.

Compressive strength increases the lifespan of briquettes by reducing the absorbing ability of moisture [72]. A minimum value of $0.38 \mathrm{MPa}$ was given as an acceptable compressive strength for briquette, which was established from a test performed on commercial fuel briquettes [80]. Similarly, Borowski and Hycnar, [89] suggested a minimum value of 1.0 MPa. The values of compressive strength for all types of briquettes in this study meets the requirements given in both studies mentioned. The high compressive strength of the hybrid briquettes makes them safer to store or transport and will not break or wear off very easily, in agreement with Nwabue et al. [90].

\subsubsection{Calorific Value}

A significant indicator of the quality of briquettes is the calorific value which measures the briquettes' energy content. It is known as the amount of heat that is formed when a briquette is burnt out completely and the products of combustion are cooled. The findings in this study shows that OPTB briquette had the highest calorific value of $17.78 \mathrm{MJ} / \mathrm{kg}$ compared with the $\mathrm{CC}$ and the hybrid briquettes (Figure 6). They, however, do not significantly differ from each other $(p<0.05)$. (Table 4$)$. These values compare well with $16.68 \mathrm{MJ} / \mathrm{kg}$ paper/sawdust briquettes [91], but are higher than the 10.26 to 
13.70 MJ/kg of vegetable market waste briquettes [92] and $15.61 \mathrm{MJ} / \mathrm{kg}$ of rice straw briquettes [93]. The proximate and elemental analysis of the biomass materials (Table 2) suggests they had adequate thermal characteristics which consequently contributed to the relatively high and acceptable calorific values observed. Corncob has a higher cellulose content (40\%) than its lignin content [22]. Higher lignin content in OPT could have also contributed to the higher calorific value of the OPTB briquette because lignin yields more energy when burned than cellulose [66].

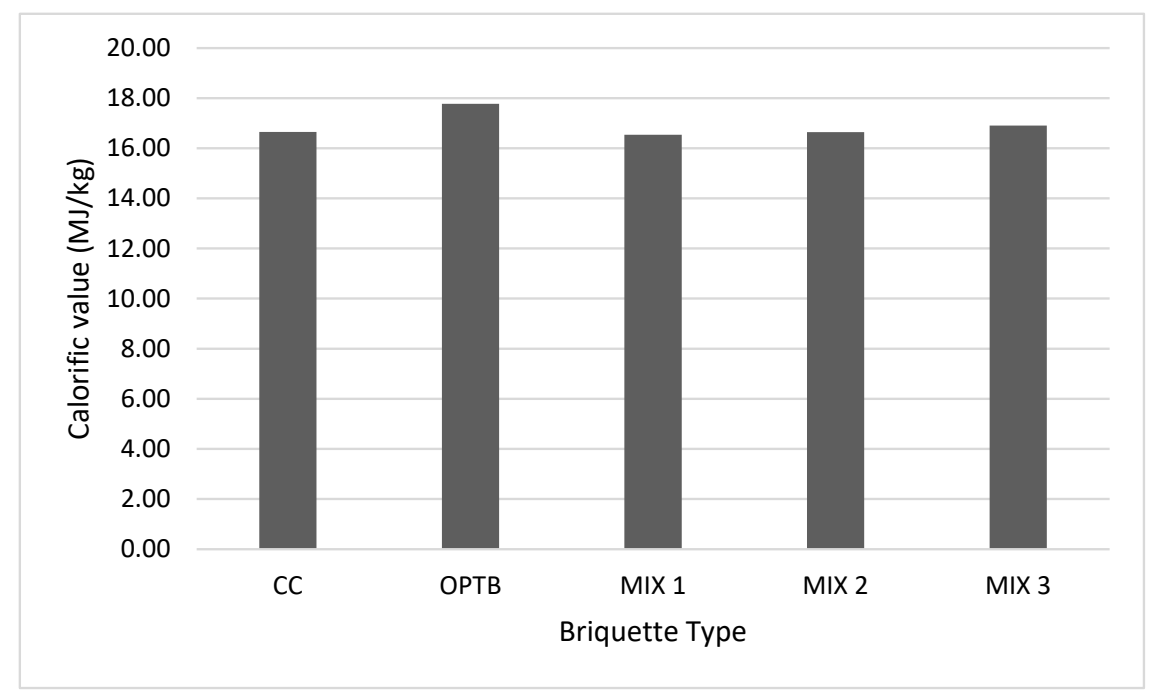

Figure 6. Calorific value of briquettes.

Fuelwood which is used for cooking, heating and lighting, especially in rural communities of developing countries has calorific values between 15.4 to $16.2 \mathrm{MJ} / \mathrm{kg}$ [94]. A calorific value of $11.66 \mathrm{MJ} / \mathrm{kg}$ is sufficient to sustain combustion as observed in Romallosa and Kraft, [44]. The conditions above implies that the calorific values of CC, OPTB and the hybrid briquettes are adequate to produce enough heat for domestic cooking applications and thus provide a potential energy source. They also meet the minimum values $(\geq 16.0 \mathrm{MJ} / \mathrm{kg})$ set by Wood Pellet Association of Canada as cited in Mitchual et al. [46] While the OPTB briquette displayed a higher calorific value, the possibility of burning with greater ash content presents the hybrid briquettes as preferable option. This is consistent with Loh, [33] in stating that a very limited amount of ash during combustion of the material is a characteristic of a good solid fuel. The production and adoption of these hybrid briquettes as alternative energy sources significantly reduces the dependence on fuelwood for heating and cooking.

\subsection{Correlation between Density and Some Briquette Properties}

Density is one of the major indices used for assessing the handling characteristics, combustion and ignition behavior of briquettes [14]. In this study, significant positive correlations were noticed between density and compressive strength $(r=0.89)$, water resistance $(r=0.96)$, calorific value $(\mathrm{r}=0.83)$ and significant negative correlation with moisture content $(\mathrm{r}=-0.91)$. The briquettes with the highest densities (OPTB and MIX 3) displayed corresponding high compressive strengths and water resistant indices. A strong correlation between unit density and compression strength was found by Rhén et al. [95]. This was further confirmed by Taulbee et al. [96], who suggested that the strength of briquettes is improved when the density is increased. Gendek et al. [84] also reported a strong correlation between density and compressive strengths in briquettes made of crushed pine, spruce and larch cones. However, the study noted a certain inconsistency with pine cone due to low compressive strength and assumed that it might be due to the contents of lignin and cellulose or resin content. Briquette's resistance to water penetration may also be dependent on its density. The more compact and less porous the particles are, the less water the briquettes will absorb. The correlation observed is expected because of the effectiveness of the inter-particle bonding. According to Tumuluru et al. [71], 
briquettes with higher densities generally have higher calorific values. Emerhi [97] reported that the higher calorific values obtained may have been a result of the density of the briquette material. The densities obtained in this study may have fallen short of the specific gravity of fuel briquettes (0.5-1.2) as noted in Antwi-Boasiako and Acheampong, [56], yet it was suggested that there is little gain in making denser briquettes as they might pose difficulty in burning $[73,86]$. Moisture content was found to have a strong positive influence on bulk density of briquettes in Karunanithy et al. [31]. The negative correlation between moisture content and density may not necessarily affect the briquettes quality in this study, except when the moisture content is above a certain limit [42].

\section{Conclusions}

The objective of this study was to investigate the quality of hybrid briquettes developed from corn cobs and the bark of oil palm trunk. Wastepaper pulp was utilized as a binding agent to allow for agglomeration from a low-pressure densification technique. Briquettes were produced from individual materials as controls and from a mixture of both in different proportions. The tests performed on the briquettes were in respect of their physical, mechanical and thermal properties. Results from the experiment showed that all the briquettes have adequate handling, transport and storage characteristics. Additionally, the relatively high heating value of the briquettes presents an attractive option as an energy source. Specifically, the OPTB briquette displayed the greatest qualities, however chances are that it will burn, leaving behind a significant quantity of ash. The relatively low ash content of corn cob added to OPTB can address this drawback, which presents the hybrid briquettes as favorable options. The significant qualities of the hybrid briquettes have confirmed and justified the use of the bark of oil palm trunk which hitherto, has not been used for briquette production. Further studies involving an optimization process varying the feedstock property (particle size and moisture content) and compression conditions (pressure and temperature) are recommended. The study also recommends a further assessment of the thermal properties of the briquettes, as well their performance in cooking applications. The use of these materials as alternative sources of energy is desirable because it could tackle problems of waste disposal, energy shortages as well as mitigate against indoor air pollution. The extraction of useful energy from a blend of corncob and OPTB could bring significant environmental and socio-economic benefits to rural communities of developing countries, including Nigeria.

Author Contributions: The following research activities were performed by specific authors: Conceptualization, S.Y.K. and M.F.Z.; Funding acquisition, M.F.Z.; Methodology, S.Y.K.; Resources, M.F.Z. and A.M.R.; Supervision, M.F.Z. and L.A.M.; Validation, L.A.M. and A.M.R.; Visualization, A.M.R.; Writing-original draft, S.Y.K.; Writing-review and editing, M.F.Z., L.A.M. and A.M.R. All authors have read and agreed to the published version of the manuscript.

Funding: This study is supported by the Ministry of Education Malaysia (MOE) Fundamental Research Grant Scheme (FRGS) 2019-1.

Acknowledgments: The authors wish to thank Abdul Ghafar and Mohamad Azrul Gani of the dry lab in the Faculty of Environmental Studies and Zarry Mohamad and Nurul Atiqah Osman of the Biorefinery Complex in the Faculty of Biotechnology and Biomolecular Science. All of these faculties are in UPM.

Conflicts of Interest: The authors declare that there is no conflict of interest.

\section{References}

1. Demirbas, A. the Combustion characteristics of different biomass fuels. Prog. Energy Combust. Sci. 2004, 30, 219-230. [CrossRef]

2. Trubetskaya, A.; Leahy, J.J.; Yazhenskikh, E.; Müller, M.; Layden, P.; Johnson, R.; Ståhl, K.; Monaghan, R.F.D. Characterization of woodstove briquettes from torrefied biomass and coal. Energy 2019, 171, 853-865. [CrossRef]

3. Sawadogo, M.; Kpai, N.; Tankoano, I.; Tanoh, S.T.; Sidib, S. Cleaner production in Burkina Faso: Case study of fuel briquettes made from cashew industry waste. J. Clean. Prod. 2018, 195, 1047-1056. [CrossRef]

4. Duca, D.; Riva, G.; Foppa Pedretti, E.; Toscano, G. Wood pellet quality with respect to en 14961-2 standard and certifications. Fuel 2014, 135, 9-14. [CrossRef] 
5. Ndindeng, S.A.; Mbassi, J.E.G.; Mbacham, W.F.; Manful, J.; Graham-Acquaah, S.; Moreira, J.; Dossou, J.; Futakuchi, K. Quality optimization in briquettes made from rice milling by-products. Energy Sustain. Dev. 2015, 29, 24-31. [CrossRef]

6. Lubwama, M.; Yiga, V.A. Development of groundnut shells and bagasse briquettes as sustainable fuel sources for domestic cooking applications in Uganda. Renew. Energy 2017, 111, 532-542. [CrossRef]

7. Zheng, S.; Liang, W.; Chu, H.; Zhou, H. Effects of radiation reabsorption of C1-C6 hydrocarbon flames at normal and elevated pressures. Fuel 2020, 266, 117061. [CrossRef]

8. Felfli, F.F.; Mesa, P.J.M.; Rocha, J.D.; Filippetto, D.; Luengo, C.A.; Pippo, W.A. Biomass briquetting and its perspectives in Brazil. Biomass Bioenergy 2011, 35, 236-242. [CrossRef]

9. Araújo, S.; Vilas Boas, M.A.; Neiva, D.M.; Carneiro, A.C.; Vital, B.; Breguez, M.; Pereira, H. Effect of a mild torrefaction for production of eucalypt wood briquettes under different compression pressures. Biomass Bioenergy 2016, 90, 181-186. [CrossRef]

10. Sepúlveda, F.J.; Arranz, J.I.; Miranda, M.T.; Montero, I.; Rojas, C.V. Drying and pelletizing analysis of waste from cork granulated industry. Energies 2018, 11, 109. [CrossRef]

11. Kpalo, S.Y.; Zainuddin, M.F.; Halim, H.B.A.; Ahmad, A.F.; Abbas, Z. Physical characterization of briquettes produced from paper pulp and Mesua ferrea mixtures. Biofuels 2019, 1-8. [CrossRef]

12. Mendoza-Martinez, C.L.; Sermyagina, E.; Carneiro, O.A.D.C.; Vakkilainen, E.; Cardoso, M. Production and characterization of coffee-pine wood residue briquettes as an alternative fuel for local firing systems in Brazil. Biomass Bioenergy 2019, 123, 70-77. [CrossRef]

13. Oladeji, J.T. Fuel Characterization of Briquettes Produced from Corncob and Rice Husk Resides. Pac. J. Sci. Technol. 2010, 11, 101-106.

14. Sotannde, O.A.; Oluyege, A.O.; Abah, G.B. Physical and combustion properties of briquettes from sawdust of Azadirachta indica. J. For. Res. 2010, 21, 63-67. [CrossRef]

15. Cooper, C.J.; Laing, C.A. A macro analysis of crop residue and animal wastes as a potential energy source in Africa. J. Energy S. Afr. 2007, 8, 10-19. [CrossRef]

16. Muazu, R.I.; Stegemann, J.A. Effects of operating variables on durability of fuel briquettes from rice husks and corn cobs. Fuel Process Technol. 2015, 133, 137-145. [CrossRef]

17. Miranda, M.T.; Sepúlveda, F.J.; Arranz, J.I.; Montero, I.; Rojas, C.V. Analysis of pelletizing from corn cob waste. J. Environ. Manag. 2018, 228, 303-311. [CrossRef]

18. Oladeji, J.T.; Enweremadu, C.C. The Effects of Some Processing Parameters on Physical and Densification Characteristics of Corncob Briquettes. Int. J. Energy Eng. 2012, 2, 22-27. [CrossRef]

19. Zubairu, A.; Gana, S.A. Production and Characterization of Briquette Charcoal by Carbonization of Agro-Waste. Energy Power 2014, 4, 41-47.

20. Adetogun, A.C.; Ogunjobi, K.M.; Are, D.B. Combustion properties of briquettes produced from maize cob of different particle sizes. J. Res. For. Wildl. Environ. 2014, 6, 28-38.

21. Okot, D.K.; Bilsborrow, P.E.; Phan, A.N. Effects of operating parameters on maize COB briquette quality. Biomass Bioenergy 2018, 112, 61-72. [CrossRef]

22. Kaliyan, N.; Morey, R.V. Densification characteristics of corn cobs. Fuel Proc. Technol. 2010, 91, 559-565. [CrossRef]

23. Mitchual, S.J.; Frimpong-Mensah, K.; Darkwa, N.A.; Akowuah, J.O. Briquettes from maize cobs and Ceiba pentandra at room temperature and low compacting pressure without a binder. Int. J. Energy Environ. Eng. 2013, 4, 1-7. [CrossRef]

24. Martinov, M.L.; Veselinov, B.V.; Bojić, S.J.; Djatkov, D.M. Investigation of maize cobs crushing-Preparation for use as a fuel. Therm. Sci. 2011, 15, 235-243. [CrossRef]

25. Dungani, R.; Jawaid, M.; Khalil, H.A.; Jasni, J.; Aprilia, S.; Hakeem, K.R.; Hartati, S.; Islam, M.N. A review on quality enhancement of oil palm trunk waste by resin impregnation: Future materials. BioResources 2013, 8, 3136-3156. [CrossRef]

26. Jalil, R.; Ibrahim, W.A.; Elham, P.; Sarif, M. Towards Zero Waste Production of Value Added Products from Waste Oil Palm Trunk (WOPT). In Proceedings of the 8th Biomass Asia Workshop, Hanoi, Vietnam, 29 November-1 December 2011; pp. 1-7.

27. Rosli, F.; Mohd, C.; Ghazali, R.; Al, M.M.; Abdullah, B.; Hussin, K. A Review: Characteristics of Oil Palm Trunk (OPT) and Quality Improvement of Palm Trunk Plywood by Resin Impregnation Fauhan. BioResources 2016, 11, 5565-5580. 
28. Onoja, E.; Chandren, S.; Abdul Razak, F.I.; Mahat, N.A.; Wahab, R.A. Oil Palm (Elaeis guineensis) Biomass in Malaysia: The Present and Future Prospects. Waste Biomass Valorization 2019, 10, 2099-2117. [CrossRef]

29. Ramamoorthy, N.K.; Tr, T.R.; Sahadevan, R. Production of bioethanol by an innovative biological pre-treatment of a novel mixture of surgical waste cotton and waste card board. Energy Sources Part A Recover Util. Environ. Eff. 2019, 1-12. [CrossRef]

30. Tursi, A. A review on biomass: Importance, chemistry, classification, and conversion. Biofuel Res. J. 2019, 22, 962-979. [CrossRef]

31. Karunanithy, C.; Wang, Y.; Muthukumarappan, K.; Pugalendhi, S. Physiochemical characterization of briquettes made from different feedstocks. Biotechnol. Res. Int. 2012, 2012, 41-48. [CrossRef]

32. Abnisa, F.; Arami-Niya, A.; Wan Daud, W.M.A.; Sahu, J.N.; Noor, I.M. Utilization of oil palm tree residues to produce bio-oil and bio-char via pyrolysis. Energy Convers. Manag. 2013, 76, 1073-1082. [CrossRef]

33. Loh, S.K. The potential of the Malaysian oil palm biomass as a renewable energy source. Energy Convers. Manag. 2017, 141, 285-298. [CrossRef]

34. Grover, P.D.; Mishra, S.K. Biomass Briquetting: Technology and Practices. Regional Wood Energy Development Programme In Asia; Field Document No 46; Food and Agriculture Organization: Rome, Italy, 1996.

35. Husain, Z.; Zainac, Z.; Abdullah, Z. Briquetting of palm fibre and shell from the processing of palm nuts to palm oil. Biomass Bioenergy 2002, 22, 505-509. [CrossRef]

36. Faizal, H.M.; Latiff, Z.A.; Wahid, M.A.; Darus, A.N. Physical and Combustion Characteristics of Biomass Residues from Palm Oil Mills; Mastorakis, N., Mladenov, V., Bojkovic, Z., Eds.; New Aspects of Fluid Mechanics, Heat Transfer and Environment; Wiley: New York, NY, USA, 2010; pp. 34-38.

37. Nasrin, A.B.; Choo, Y.M.; Lim, W.S.; Joseph, L.; Michael, S.; Rohaya, M.H. Briquetting of Empty Fruit Bunch fibre and palm shell as a renewable energy fuel. J. Eng. Appl. Sci. 2011, 6, 446-451.

38. Sing, C.Y.; Aris, S.S. A study of biomass fuel briquettes from oil palm mill residues. Asian J. Sci. Res. 2013, 6, 537-545. [CrossRef]

39. Bazargan, A.; Rough, S.L.; McKay, G. Compaction of palm kernel shell biochars for application as solid fuel. Biomass Bioenergy 2014, 70, 489-497. [CrossRef]

40. Hamid, M.F.; Idroas, M.Y.; Ishak, M.Z.; Zainal Alauddin, Z.A.; Miskam, M.A.; Abdullah, M.K. An Experimental Study of Briquetting Process of Torrefied Rubber Seed Kernel and Palm Oil Shell. Biomed. Res. Int. 2016, 2016, 1679734. [CrossRef]

41. Mitchual, S.J.; Frimpong-Mensah, K.; Darkwa, N.A. Effect of species, particle size and compacting pressure on relaxed density and compressive strength of fuel briquettes. Int. J. Energy Environ. Eng. 2013, 4, 30. [CrossRef]

42. Yank, A.; Ngadi, M.; Kok, R. Physical properties of rice husk and bran briquettes under low pressure densification for rural applications. Biomass Bioenergy 2016, 84, 22-30. [CrossRef]

43. Muazu, R.I.; Stegemann, J.A. Biosolids and microalgae as alternative binders for biomass fuel briquetting. Fuel 2017, 194, 339-347. [CrossRef]

44. Romallosa, A.; Kraft, E. Feasibility of Biomass Briquette Production from Municipal Waste Streams by Integrating the Informal Sector in the Philippines. Resources 2017, 6, 12. [CrossRef]

45. Harun, N.Y.; Parvez, A.M.; Afzal, M.T. Process and energy analysis of pelleting agricultural and woody biomass blends. Sustainability 2018, 10, 1770. [CrossRef]

46. Mitchual, S.J.; Katamani, P.; Afrifa, K.A. Fuel characteristics of binder free briquettes made at room temperature from blends of oil palm mesocarp fibre and Ceiba pentandra. Biomass Convers. Biorefinery 2019, 9,541-551. [CrossRef]

47. Mitchual, S.J.; Frimpong-Mensah, K.; Darkwa, N.A. Relationship between Physico-Mechanical Properties, Compacting Pressure and Mixing Proportion of Briquettes Produced from Maize Cobs and Sawdust. J. Sustain. Bioenergy Syst. 2014, 4, 50-60. [CrossRef]

48. Roy, R.; Kundu, K.; Kar, S.; Dahake, V.R.; Rajan, P. Production and evaluation of briquettes made from dry leaves, wheat straw, saw dust using paper pulp and cow dung as binder. Res. Front. 2015, 3, 51-58.

49. ASTM D3175-18. Standard Test Method for Volatile Matter in the Analysis Sample of Coal and Coke; ASTM International: West Conshohocken, PA, USA, 2018.

50. ASTM D3174-12. Standard Test Method for Ash in the Analysis Sample of Coal and Coke from Coal; ASTM International: West Conshohocken, PA, USA, 2012. 
51. ASTM D3176-15. Standard Practice for Ultimate Analysis of Coal and Coke; ASTM International: West Conshohocken, PA, USA, 2015.

52. ASTM D2444-16. Standard Test Methods for Direct Moisture Content Measurement of Wood and Wood-Based Materials; ASTM International: West Conshohocken, PA, USA, 2016.

53. ASTM D2395-17. Standard Test Methods for Density and Specific Gravity (Relative Density) of Wood and Wood-Based Materials; ASTM International: West Conshohocken, PA, USA, 2017.

54. Davies, R.M.; Davies, O.A. Physical and combustion characteristics of briquettes made from water hyacinth and phytoplankton scum as binder. J. Combust. 2013, 2013, 549894. [CrossRef]

55. ASTM D440-86. Standard Test Method of Drop Shatter Test for Coal; ASTM International: West Conshohocken, PA, USA, 2002.

56. Antwi-Boasiako, C.; Acheampong, B.B. Strength properties and calorific values of sawdust-briquettes as wood-residue energy generation source from tropical hardwoods of different densities. Biomass Bioenergy 2016, 85, 144-152. [CrossRef]

57. ASTM D2166-85. Standard Test Method of Compressive Strength of Wood; ASTM International: West Conshohocken, PA, USA, 2008.

58. ASTM D5865-13. Standard Test Method for Gross Calorific Value of Coal and Coke; ASTM International: West Conshohocken, PA, USA, 2013.

59. Khabibi, J.; Irawan, B. Proximate analysis of lignocellulosic material as alternative bioenergy resources. J. Lignocellul Technol. 2016, 1, 38-43.

60. Sette, C.R., Jr.; Hansted, A.L.S.; Novaes, E.; Lima, P.A.F.; Rodrigues, A.C.; de Souza Santos, D.R.; Yamaji, F.M. Energy enhancement of the eucalyptus bark by briquette production. Ind. Crops Prod. 2018, 122, 209-213. [CrossRef]

61. DIN51731. Testing of Solid Fuels—Compressed Untreated Wood-Requirements and Testing; German Institute for Standardisation (Deutsches Institut für Normung): Berlin, Germany, 1996.

62. Liu, X.; Chen, M.; Wei, Y. Combustion behavior of corncob/bituminous coal and hardwood/bituminous coal. Renew. Energy 2015, 81, 355-365. [CrossRef]

63. Arewa, M.E.; Daniel, I.C.; Kuye, A. Characterisation and comparison of rice husk briquettes with cassava peels and cassava starch as binders. Biofuels 2016, 7, 671-675. [CrossRef]

64. Chin, O.C.; Siddiqui, K.M. Characteristics of some biomass briquettes prepared under modest die pressures. Biomass Bioenergy 2000, 18, 223-228. [CrossRef]

65. Missagia, B.; Guerrero, C.; Narra, S.; Sun, Y.; Ay, P.; Krautz, H.J. Physicomechanical properties of rice husk pellets for energy generation. Energy Fuels 2011, 25, 5786-5790. [CrossRef]

66. Tumuluru, S.J.; Wright, C.T.; Hess, J.R.; Kenney, K.L. A review of biomass densifi cation systems to develop uniform feedstock commodities for bioenergy application. Biofuels Bioprod. Bioref. 2011, 5, 683-707. [CrossRef]

67. Ahmad, K.K.Z.; Sazali, K.; Kamarolzaman, A.A. Characterization of fuel briquettes from banana tree waste. In Materials Today: Proceedings; Elsevier Ltd.: Amsterdam, The Netherlands, 2018; pp. 21744-21752.

68. Miranda, T.; Montero, I.; Sepúlveda, F.; Arranz, J.; Rojas, C.; Nogales, S. A Review of Pellets from Different Sources. Materials 2015, 8, 1413-1427. [CrossRef]

69. Onukak, I.; Mohammed-Dabo, I.; Ameh, A.; Okoduwa, S.; Fasanya, O. Production and Characterization of Biomass Briquettes from Tannery Solid Waste. Recycling 2017, 2, 17. [CrossRef]

70. Moreno, A.I.; Font, R.; Conesa, J.A. Physical and chemical evaluation of furniture waste briquettes. Waste Manag. 2016, 49, 245-252. [CrossRef]

71. Tumuluru, S.J.; Christopher, W.T.; Kenny, K.L.; Hess, J.R. A Review on Biomass Densification Technologies for Energy Application; Idaho National Laboratory: Falls, Idaho, 2010.

72. Kers, J.; Kulu, P.; Aruniit, A.; Laurmaa, V.; Krizan, P.; Soos, L.; Kask, Ü. Determination of physical, mechanical and burning characteristics of polymeric waste material briquettes. Est. J. Eng. 2010, 16, 307-316. [CrossRef]

73. Eriksson, S.; Prior, M. The Briquetting of Agricultural Wastes for Fuel, 11th ed.; FAO: Rome, Italy, 1990; 137p.

74. Onchieku, J.M. Cost Benefit Analysis of Making Charcoal Briquettes Using Screw Press Machine Locally Designed and Fabricated. Int. Adv. Res. J. Sci. Eng. Technol. 2018, 5, 57-65.

75. Olorunnisola, A. Production of Fuel Briquettes from Waste Paper and Coconut Husk Admixtures. CIGR Ejournal 2007, 9, 1-11.

76. Rajaseenivasan, T.; Srinivasan, V.; Syed Mohamed Qadir, G.; Srithar, K. An investigation on the performance of sawdust briquette blending with neem powder. Alex. Eng. J. 2016, 55, 2833-2838. [CrossRef] 
77. Pinto, J.; Cruz, D.; Paiva, A.; Pereira, S.; Tavares, P.; Fernandes, L.; Varum, H. Characterization of corn cob as a possible raw building material. Constr. Build. Mater. 2012, 34, 28-33. [CrossRef]

78. Sukiran, M.A.; Abnisa, F.; Wan Daud, W.M.A.; Abu Bakar, N.; Loh, S.K. A review of torrefaction of oil palm solid wastes for biofuel production. Energy Convers. Manag. 2017, 149, 101-120. [CrossRef]

79. Yaman, S.; Şahan, M.; Haykiri-Açma, H.; Şeşen, K.; Küçükbayrak, S. Fuel briquettes from biomass-lignite blends. Fuel Process Technol. 2001, 72, 1-8. [CrossRef]

80. Richards, S.R. Physical Testing of Fuel Briquettes. Fuel Process Technol. 1990, 25, 89-100. [CrossRef]

81. Ajiboye, T.; Abdulkareem, S.; Anibijuwon, A.O.Y. Investigation of mechanical properties of briquette product of sawdust-charcoal as a potential domestic energy source. J. Appl. Sci. Environ. Manag. 2017, 20, 1179. [CrossRef]

82. Borowski, G.; Stępniewski, W.; Wójcik-Oliveira, K. Effect of starch binder on charcoal briquette properties. Int. Agrophys. 2017, 31, 571-574. [CrossRef]

83. Ujjinappa, S.; Sreepathi, L.K. Production and quality testing of fuel briquettes made from pongamia and tamarind shell. Sadhana 2018, 43, 1-7. [CrossRef]

84. Gendek, A.; Aniszewska, M.; Malat'ák, J.; Velebil, J. Evaluation of selected physical and mechanical properties of briquettes produced from cones of three coniferous tree species. Biomass Bioenergy 2018, 117, 173-179. [CrossRef]

85. Deshannavar, U.B.; Hegde, P.G.; Dhalayat, Z.; Patil, V.; Gavas, S. Production and characterization of agro-based briquettes and estimation of calorific value by regression analysis: An energy application. Mater. Sci. Energy Technol. 2018, 1, 175-181. [CrossRef]

86. Mandal, S.; Prasanna Kumar, G.V.; Bhattacharya, T.K.; Tanna, H.R.; Jena, P.C. Briquetting of Pine Needles (Pinus roxburgii) and Their Physical, Handling and Combustion Properties. Waste Biomass Valorization 2019, 10, 2415-2424. [CrossRef]

87. Jamradloedluk, J.; Wiriyaumpaiwong, S. Production and Characterization of Rice Husk Based Charcoal Briquettes. KKU Eng. J. 2007, 34, 391-398.

88. Wu, S.; Zhang, S.; Wang, C.; Mu, C.; Huang, X. High-strength charcoal briquette preparation from hydrothermal pretreated biomass wastes. Fuel Process Technol. 2018, 171, 293-300. [CrossRef]

89. Borowski, G.; Hycnar, J.J. Utilization of fine coal waste as a fuel briquettes. Int. J. Coal Prep. Util. 2013, 33, 194-204. [CrossRef]

90. Nwabue, F.I.; Unah, U.; Itumoh, E.J. Production and characterization of smokeless bio-coal briquettes incorporating plastic waste materials. Environ. Technol. Innov. 2017, 8, 233-245. [CrossRef]

91. Romallosa, A.R.D. Quality Analyses of Biomass Briquettes Produced using a Jack-Driven Briquetting Machine. Int. J. Appl. Sci. Technol. 2017, 7, 8-16.

92. Srivastava, N.S.L.; Narnaware, S.L.; Makwana, J.P.; Singh, S.N.; Vahora, S. Investigating the energy use of vegetable market waste by briquetting. Renew. Energy 2014, 68, 270-275. [CrossRef]

93. Gill, N.; Dogra, R.; Dogra, B. Influence of Moisture Content, Particle Size, and Binder Ratio on Quality and Economics of Rice Straw Briquettes. Bioenergy Res. 2018, 11, 54-68. [CrossRef]

94. Engineering Tool Box. Fuels-Higher and Lower Calorific Values. Available online: https://www. engineeringtoolbox.com/fuels-higher-calorific-values-d_169.html (accessed on 30 October 2019).

95. Rhén, C.; Gref, R.; Sjöström, M.; Wästerlund, I. Effects of raw material moisture content, densification pressure and temperature on some properties of Norway spruce pellets. Fuel Process Technol. 2005, 87, 11-16. [CrossRef]

96. Taulbee, D.; Patil, D.P.; Honaker, R.Q.; Parekh, B.K. Briquetting of coal fines and sawdust part I: Binder and briquetting-parameters evaluations. Int. J. Coal Prep. Util. 2009, 29, 1-22. [CrossRef]

97. Emerhi, E.A. Physical and combustion properties of briquettes produced from sawdust of three hardwood species and different organic binders. Adv. Appl. Sci. Res. 2011, 2, 236-246.

(C) 2020 by the authors. Licensee MDPI, Basel, Switzerland. This article is an open access article distributed under the terms and conditions of the Creative Commons Attribution (CC BY) license (http://creativecommons.org/licenses/by/4.0/). 